Selcuk Journal of Agriculture and Food Sciences

http://sjafs.selcuk.edu.tr/sjafs/index

Research Article

\section{SJAFS}

(2021) 35 (2), 125-130

e-ISSN: $2458-8377$

DOI:10.15316/SJAFS.2021.238

\title{
Utilizing Spent Plantain Pseudostems to Grow Vegetables for Additional Income to Farm Households in Nigeria
}

iD Emmanuel Egbodo-Boheje ODUM ${ }^{1, *}$, iD Grace Oluwabukunmi AKINSOLA ${ }^{2}$

${ }^{1}$ University of Benin, Department of Agricultural Economics and Extension Services, Edo State, Nigeria

${ }^{2}$ University of Ilorin, Department of Agricultural Economics and Farm Management, Ilorin, Nigeria

\begin{tabular}{l}
\hline ARTICLE INFO \\
\hline Article history: \\
Received date: 27.05 .2021 \\
Accepted date: 17.06 .2021 \\
\hline
\end{tabular}

\section{Keywords:}

Farm-waste

innovation

Pseudostems

Additional income

Vegetables

Nigeria

\begin{abstract}
The study examined value addition using plantain trunks to grow vegetables as an additional source of income to farm households. Using of a questionnaire to elicit responses from 120 plantain farmers in Edo State, we used descriptive and inferential statistics to examine the socioeconomic characteristics, return to leafy vegetable production, perceived environmental impacts and the challenges to adopting the innovation. Results from the study show that $62 \%$ of respondents were females. Lettuce and Spinach were the prevalent leafy vegetables grown. The return to leafy vegetable production was NGN, $258,378.42 \mathrm{~K} / \mathrm{Ha} /$ season fewer production costs. This return was $39 \%$ of the average returns to plantain production/Ha/Year. Decaying pseudostems adding to the manure to the soil through humus formation and reduced pollution from agrochemicals and fertilizers were some of the perceived environmental impacts of the innovation. Low market prices of vegetables, shortness of the shelf life of vegetables, costs of seeds were the major challenges encountered by farmers who adopted the innovation. The study concludes that the innovation was viable with the possibility of expansion. The study recommends further drive of the innovation to other plantain producing regions of Nigeria, and plantain farmers are also encouraged to explore other uses of their farm "waste", environmental specialist and other promoters of ecofriendly production and investors should partner with these plantain producers to add value to products and 'wastes'. The right and supporting policies to sustain the adoption of the innovation should also be put in place by the authorities concerned.
\end{abstract}

\section{Introduction}

Plantain belongs to the family of plants called "Musaceae", and the principal species are Musa paradisca (French plantain), Musa acuminata (genome AA- Gross Michel and Cavendish) and Musa. corniculata (Horn plantain) whose production requires an optimum temperature of $30^{\circ} \mathrm{C}$, mean monthly rainfall of $100 \mathrm{~mm}$, soil $\mathrm{pH}$ of $4.5-7.5$ and a partly drained sandy-loam soil (Ekunwe and Ajayi 2010; Ajiboye and Olaniyan 2016). Plantain is mainly grown in the tropical and subtropical countries and are widely used for its nutritional values all over the world (Imam and Akter 2011) and is one of the most important horticultural crops contributing to food security and alleviating hunger globally and serving as an important staple food for both rural and urban populace (USD, 2012). It meets their day-to-day food requirement in the form of chips, flour, flakes, cakes, fried plantain,

\footnotetext{
* Corresponding author email: odumboheje@gmail.com
}

roasted plantain, and so many other forms of culinary provisions, thereby contributing to the fight against food insecurity/poverty (Ojeniran et al. 2018). Nigeria is one of the largest producers of plantain globally and is ranked 7 th in Africa and 15th in the world, producing 3,093,372 metric tons (FAOSTAT 2018). Ekunwe and Ajayi (2010); Akinyemi et al. (2017), and Elum and Tigiri (2018) listed Edo State as one of the States within the Southern Belt of Nigeria that grows plantain.

Whatever the variety of the fruit, all the parts of a Plantain plant have some use. However, the edible or direct human uses are considered while little or no attention is paid to the indirect uses. Imam and Akter (2011) and Okoli (2020a;b;c) and Voilette (2019) all posited that all the parts of the Plantain plant: fruit, peel, leaf, stem, stalk, and inflorescence (flower), can be utilized in agriculture and cottage industries. They are used in numerous food and non-food-related applications such as thickeners, colorants and flavorings, macro and micro-nutrient sources, livestock feed, fibres, bioactive compound sources, and organic fertilizers. Additionally, all parts of the Plantain plant 
have some medical values, for example, the flower can be cooked and consumed by diabetic, respiratory, dysentery, and ulcer patients. The stem sap can be administered orally or applied externally against stings and bites. The roots, ashed leaves, peels, and seeds are equally used for therapeutic purposes in some countries. The Plantain stem can be processed into pulp and paper raw material, fiber for textiles, and fillers, or structural reinforcement in composites materials.

Okoli (2020a) asserts that in many Plantain producing countries, particularly in Africa, Plantains are farmed for the fruits only, while the other parts are discarded as waste. Farm wastes are the by-products of farm activities and are so referred because they are not the primary products and could take the form of crop residues (residual stems, stalks, straw, leaves, roots, husks, shells) and animal waste (dungs) which are usually available, renewable and virtually free. They can be converted into a resource and raw materials that can be used for animal feed and composting, among others (Sabiiti 2011). It has been estimated that one hectare of the Plantain farm could produce approximately 220 tons of biomass wastes made of leaves, midrib, dried leaf sheath, pseudostem, and inflorescent flower. In Africa, these wastes are usually left on the farm to decay or are disposed of simply by burning. In large plantations, the disposal of large quantities of Plantain wastes can be costly, and constitute a major operation in order to avoid environmental damage and litigations (Okoli 2020b). Similarly, Obi et al. (2016) define farm wastes as the residues from the growing and processing raw farm products such as fruits, vegetables, meat, poultry, dairy products, and crops. They are the non-product outputs of the production and processing of agricultural products that may contain material that can benefit man but whose economic values are less than collection costs, transportation, and processing for beneficial use. This spells the necessity of utilizing farm waste as a resource to further production instead of discarding or leaving them to rot or even outright burning them in the field as obtained in developing countries. This is achievable through the process of innovation that Toborn (2011) defined as an idea, practice or object perceived as new by an individual or other unit of adoption.

On the attempts to use plantain waste, Belewu and Belewu (2005) explored the potential of Plantain leaves as a good substrate for the cultivation of $V$. volvacea and the spent substrate as a viable ingredient in ruminant feed, Phirke et al. (2001) stated that the Pseudo stem of plantain can be used for bio-fertilizer production and was supported by Kamira et al. (2015) as a source of compost manure and Vermicomposting. Okoli (2020b) also asserts that every part of the Plantain pseudostem can be converted into useful products using some simple techniques and technologies in turning such Plantain wastes into valueadded by Plantain producers in Africa to generate extra income by creating lots of employment opportunities, especially for rural woman and unemployed youths, thereby improving their socioeconomic wellbeing.

While Lekshmi (2018) asserts that plantain trunk waste is used in Indonesia as planting material for growing short-root plants such as vegetables, he describes the innovation as having a positive effect on the country's agricultural scenario reduced tonnes of Plantain plant wastage that occurs regularly. The use of plantain stems from growing vegetables, as outline by Lekshmi (2018) entails digging appropriate holes (according to your crop or garden plant's features) in the stem with a knife, fill these with good loamy soil and plant the seeds into the pits at a spacing of $30-$ $40 \mathrm{~cm}$ between seedlings to avoid clustering, ensure proper aeration and balanced growth of plants. He further itemized the advantages of this innovation to include zero irrigation as the plantain stem has fantastic water retention abilities, so the plants absorb water from the stem and nutrients from the soil filled in the pits. There is a low chance of weed infestation, and the innovation encourages the availability of vegetables around the year irrespective of the season. Plantain stem cultivation can become the next revolutionary hack in the field of agriculture with the hope of bringing respite and good returns to the farmers. Ahmar (2021) describes the use of plantain stems to grow vegetables as an Organic farming innovation known for helping in minimizing space and resources principally because Plantain stems are easily available to farmers and serve as excellent devices for organic farming, particularly when their space is scarce. Therefore, he called for its drive especially in rural agriculture development that can help attain both the objectives of organic food and eliminate irrigation costs and further stated that rotten Plantain stems after use adds manures to the soil. It is, however, important to chop these into small pieces before they are used as a fertilizer. This helps to ensure that they do not become a hiding place for insects. The wonderful concept can go a long way in ensuring rural independence and cut away farmers' overreliance on rains or irrigation for moisture.

Adeoye et al. (2013) reviewed the significant contributions of plantain to the economic development and food security of both rural and urban households in Nigeria and outlined the need to understand the network, linkages, flow, volume and value added among the Plantain Value Chain actors. Despite several studies on the usefulness of plantains such as that Mohapatra et al. (2010), Ojeniran et al. (2018) and Okoli $(2020 \mathrm{a} ; \mathrm{b} ; \mathrm{c})$, there have been the concern of underutilization of some products of plantain and an assertion that some other potentials of plantain have not been discovered (Lekshmi 2018). In tandem with the study of Imam and Akter (2011) and Lekshmi (2018) that potentials of plantain based on the uses remain unexplored, limited and in-exhaustive, this study therefore explored the use of plantain trunks considered as a farm waste to grow vegetables in Nigeria as a source for additional farm income. 
Specifically, we examine the socioeconomic characteristics of farmers who adopted the innovation, identified the types of vegetables grown using this innovation, return to leafy vegetable production, perceived environmental benefits and the challenges to adopting the innovation.

\section{Materials and Methods}

\section{Study Area}

The study was conducted in Ozalla Farm Reserve area of Owan West Local Government Area (LGA) of Edo State, Nigeria. The State is an agrarian State with farming as the dominant economic activity of the State while the area is located within Longitudes $6^{\circ} 45^{\prime}$ and $6^{\circ} 45.3^{\prime}$ and Latitudes $5^{\circ} 45^{\prime}$ and $5^{\circ} 47.5^{\prime} \mathrm{E}$. The area has a tropical climate characterized by two distinct seasons wet and dry seasons. The Wet season occurs between April and October with a break in August and average rainfall ranging from $1800 \mathrm{~mm}-2500 \mathrm{~mm}$ while the dry season lasts from November to April. The harmattan season is experienced between December and January. The various periods highlighted may vary slightly from recent climate change (Talabi et al. 2016). The target population for the study was an adopter of the innovation among plantain farmers in the Farm reserve area.

\section{Experimental Design and method of data analysis}

A two-stage purposive sampling procedure was employed for the study. The first stage involved the purposive sampling of Owan West LGA among the plantain producing LGA's. The second stage involved the selection of 120 plantain farmers who adopted the innovation.

Descriptive statistics of Frequencies tables and percentages was used to examine socioeconomic characteristics, perceived environmental impacts and the challenges to adopting the innovation while Net farm Income model was used to estimate the return to leafy vegetable production,

\section{Model specification}

Net Farm Income is the difference between gross income and total costs of production. Algebraically as adapted from Obalola, Agboola and Odum (2017), it is specified as:

$\mathrm{GM}=\mathrm{TR}-\mathrm{TVC}$

And

$\mathrm{NFI}=\mathrm{TR}-\mathrm{TC}$

Since,

$\mathrm{TC}=\mathrm{TVC}+\mathrm{TFC}$

Then

$\mathrm{RTN}=\mathrm{TR} / \mathrm{TC}$

Where,

$\mathrm{GM}=$ Gross Margin (NGN)

$\mathrm{TR}=$ Total Revenue $(\mathrm{NGN})$

$\mathrm{TC}=$ Total Cost $(\mathrm{NGN})$
TVC $=$ Total Variable Costs of production (NGN);

$\mathrm{TFC}=$ Total Fixed Costs of production $(\mathrm{NGN})$;

$\mathrm{TC}=$ Total Cost;

NFI $=$ Net Farm Income $($ NGN $)$

$\mathrm{RTN}=$ Return to Naira invested

\section{Results and Discussion}

\subsection{Socioeconomic report of respondents}

The socioeconomic respondents who participated in using spent plantain pseudostems to grow vegetables for additional farm income is presented in Table 1.

Table 1

Socioeconomic report of respondents

\begin{tabular}{|c|c|c|}
\hline Variable & $\begin{array}{c}\text { Frequency } \\
(\mathrm{N}=120)\end{array}$ & Percentage $(\%)$ \\
\hline \multicolumn{3}{|l|}{ Gender } \\
\hline Male & 46 & 38 \\
\hline Female & 74 & 62 \\
\hline \multicolumn{3}{|l|}{ Age (years) } \\
\hline$\leq 20$ & 16 & 13.3 \\
\hline $21-30$ & 30 & 25 \\
\hline $31-40$ & 30 & 25 \\
\hline $41-50$ & 24 & 20 \\
\hline$\geq 50$ & 20 & 16.7 \\
\hline Mean age & 30.5 years & \\
\hline \multicolumn{3}{|l|}{ Marital Status } \\
\hline Single & 20 & 16.7 \\
\hline Married & 50 & 50.0 \\
\hline Divorced & 10 & 8.3 \\
\hline Widowed & 30 & 25.0 \\
\hline \multicolumn{3}{|l|}{$\begin{array}{l}\text { Household Size (No. of } \\
\text { persons) }\end{array}$} \\
\hline$\leq 5$ & 20 & 16.7 \\
\hline$\overline{6}-10$ & 75 & 62.5 \\
\hline$\geq 10$ & 25 & 20.8 \\
\hline Mean Household Size & 8 persons & \\
\hline \multicolumn{3}{|l|}{ Level of Education } \\
\hline No formal Education & 25 & 20.8 \\
\hline Primary/Basic & 35 & 29.2 \\
\hline Secondary & 40 & 33.3 \\
\hline Tertiary & 20 & 16.7 \\
\hline \multicolumn{3}{|l|}{ Farm Size $(\mathrm{Ha})$} \\
\hline$\leq 5$ & 25 & 20.8 \\
\hline $6-10$ & 60 & 50.0 \\
\hline$\geq 10$ & 35 & 29.2 \\
\hline Mean Farm Size & 8 Hectares & \\
\hline \multicolumn{3}{|l|}{$\begin{array}{l}\text { Farming Experience } \\
\text { (Years) }\end{array}$} \\
\hline$\leq 5$ & 10 & 8.3 \\
\hline $6-10$ & 50 & 41.7 \\
\hline $11-15$ & 40 & 33.3 \\
\hline$\geq 15$ & 20 & 16.7 \\
\hline Mean Farming Experience & 10years & \\
\hline \multicolumn{3}{|l|}{$\begin{array}{l}\text { Income } \\
\text { level(NGN/Ha/Cycle) }\end{array}$} \\
\hline$\leq 300,000$ & 45 & \\
\hline $300,000-600,000$ & 60 & \\
\hline$\geq 600,000$ & 15 & \\
\hline Mean income & $\begin{array}{c}\text { NGN/Ha/Cycle } \\
662,508.77\end{array}$ & \\
\hline
\end{tabular}

The results in Table 1 show the socioeconomic characteristics of the respondents who adopted the technology. Using Plantain pseudostems to grow vegetable is a female dominated ventures as $62 \%$ of 
respondents were females. The modal age of respondents was between $21-30$ and $21-40$ with a mean age of 30.5 years. About $50 \%$ of the respondents were married while $16 / 7 \%$ were not married. The modal household size of respondents was between 6 10 persons per household while the mean household size of respondents was 8 persons. On the respondent level of education, $79.2 \%$ had a form of education or the other while $20.2 \%$ had no formal education. The respondent level of education may largely influence their willingness or not to adopt the technology. With a mean farm size of $8 \mathrm{Ha}$ and 10 years farming experience, respondents made an average of NGN662, $508.77 \mathrm{~K} / \mathrm{Ha} /$ Cycle.

\subsection{Identified vegetables grown on using the innovation}

Results in Figure 1 show that $45.6 \%$ of respondents grew lettuce; $41.7 \%$ grew onions while $12.5 \%$ grew Spinach using the spent plantain pseudostems.

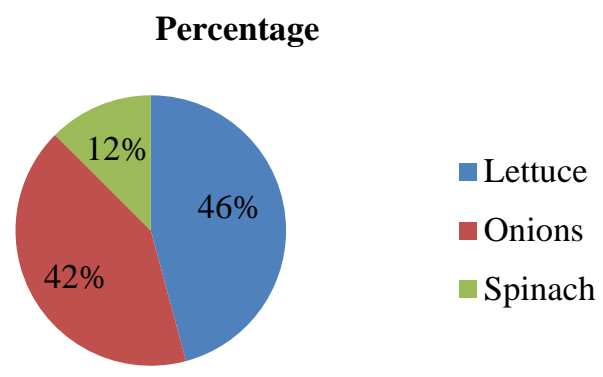

Figure 1

Vegetables grown using spent plantain pseudostem (Source: Field Survey 2020)

\subsection{Return to Vegetable production using plantain trunks for growing vegetables}

The costs and return to vegetable production using this innovation is presented in Table 2.

Using spent plantain pseudostem to grow vegetables, farmers incurred NGN 88, 202.5 as total variable cost and NGN 58,100 as total fixed cost in their production. Farmer earned a total of NGN 398, $380.92 \mathrm{k}$ as total revenue. However, they had a return (NFI) of NGN 258, 378.42/Ha/cycle less the total cost incurred in production. The use of spent plantain to grow vegetables had 2.8 as return to Naira invested which imply that for every Naira invested in the innovation a corresponding NGN 2.8 was returned as profit of investment which show that investing in the use of spent plantain psuedostems to grow vegetables is viable and should be encouraged to reduce farm waste and create some additional farm income for plantain farming households in the study area. Additionally, the costs for farm yard manure $(28.3 \%)$ and acquiring Knapsack spray tanks $(69.4 \%)$ were the highest incurred for variable cost and fixed cost, respectively.
Table 2

Return to vegetable production using spent plantain pseudostem for additional farm income

\begin{tabular}{|c|c|c|c|c|}
\hline Variable Cost & $\begin{array}{c}\text { Cost/Unit } \\
(\mathrm{NGN})\end{array}$ & Qty/Ha & $\begin{array}{c}\text { Amount } \\
(\mathrm{NGN})\end{array}$ & $\%$ \\
\hline Seeds (Kg) & 5,000 & 2 & 10,000 & 11.3 \\
\hline $\begin{array}{l}\text { Insecticides } \\
\text { (Litres) }\end{array}$ & 1,470 & 2 & 2,940 & 3.3 \\
\hline $\begin{array}{l}\text { Farm yard } \\
\text { manure }(\mathrm{Kg})\end{array}$ & 500 & 50 & 25,000 & 28.3 \\
\hline $\begin{array}{l}\text { Transportation } \\
\text { (NGN/day) }\end{array}$ & 1,630 & 12 & 19,560 & 22.2 \\
\hline $\begin{array}{l}\text { Water for } \\
\text { spraying } \\
\text { insecticides } \\
\text { (Litres) }\end{array}$ & 33.5 & 215 & $7,202.5$ & 8.2 \\
\hline $\begin{array}{l}\text { Pseudostem } \\
\text { collection and } \\
\text { preparation } \\
\text { (Manday) } \\
\text { Insecticide }\end{array}$ & 1,640 & 3 & 4,920 & 5.6 \\
\hline $\begin{array}{l}\text { Application } \\
\text { (Manday) } \\
\text { Farm }\end{array}$ & 1,580 & 3 & 4,740 & 5.4 \\
\hline $\begin{array}{l}\text { Maintenance } \\
\text { (Manday) }\end{array}$ & 2,000 & 2 & 4,000 & 4.5 \\
\hline $\begin{array}{l}\text { Harvesting/Sortin } \\
\mathrm{g} \text { (Manday) }\end{array}$ & 1,550 & 3 & 4,650 & 5.3 \\
\hline $\begin{array}{l}\text { Basketing and } \\
\text { packaging } \\
\text { (Manday) }\end{array}$ & 1,730 & 3 & 5,190 & 5.6 \\
\hline $\begin{array}{l}\text { Total Variable } \\
\text { Cost (TVC) }\end{array}$ & & & $88,202.5$ & 100 \\
\hline $\begin{array}{l}\text { Fixed Cost } \\
\text { Cutlasses } \\
\text { (NGN/Unit) }\end{array}$ & 2,000 & 4 & 8,000 & 15.4 \\
\hline $\begin{array}{l}\text { Knives } \\
\text { (NGN/Unit) }\end{array}$ & 450 & 6 & 2,700 & 5.2 \\
\hline $\begin{array}{l}\text { Basket } \\
\text { (NGN/Unit) } \\
\text { Knapsack }\end{array}$ & 1,700 & 3 & 5,100 & 10 \\
\hline $\begin{array}{l}\text { Sprayers } \\
\text { (NGN/Unit) }\end{array}$ & 12,000 & 3 & 36,000 & 69.4 \\
\hline $\begin{array}{l}\text { Total Fixed Cost } \\
\text { (TFC) }\end{array}$ & & & 51,800 & 100 \\
\hline $\begin{array}{l}\text { Total Cost (TC) } \\
\text { Revenue }\end{array}$ & & & $\begin{array}{c}140,002.5 \\
398,380.92\end{array}$ & \\
\hline Gross Margin & & & $310,178.42$ & \\
\hline $\begin{array}{l}\text { Net Farm Income } \\
\text { (NFI) }\end{array}$ & & & $258,378.42$ & \\
\hline $\begin{array}{l}\text { Return to Naira } \\
\text { invested }\end{array}$ & & & 2.8 & \\
\hline
\end{tabular}

\subsection{Perceived environmental benefits of the innovation}

On the perceived benefit of this innovation to the environment as shown in Figure 2, 50\% of respondents believe that when spent plantain pseudostems are used in growing crops, they decay, form and add humus to the soil which is an essential constituent of soil fertility and hence reduce the additional requirement for fertilizers. About $41.7 \%$ of farmers who adopted this innovation believe there will be reduced pollution due to agrochemicals and fertilizers because the innovation is soil fertility replenishing. This partly agrees with Lekshmi (2018) who stated that the innovation makes the chances of weed infestation remain relatively lower and consequently will cut off weeding cost. Also, $8.3 \%$ of respondents opined that the innovation would prevent moisture loss by plants if grown on the soil 
because plantain pseuedostems retain water over a long time. The innovation is self moisture servicing and sustaining. This is in tandem with Ahmar (2021) who stated that the innovation retains water to the tune of serving the purpose of irrigation for farmers and encourages farmers to use the plantain pseudostems for planting short root crops.

Percieved benefits of the the innovation

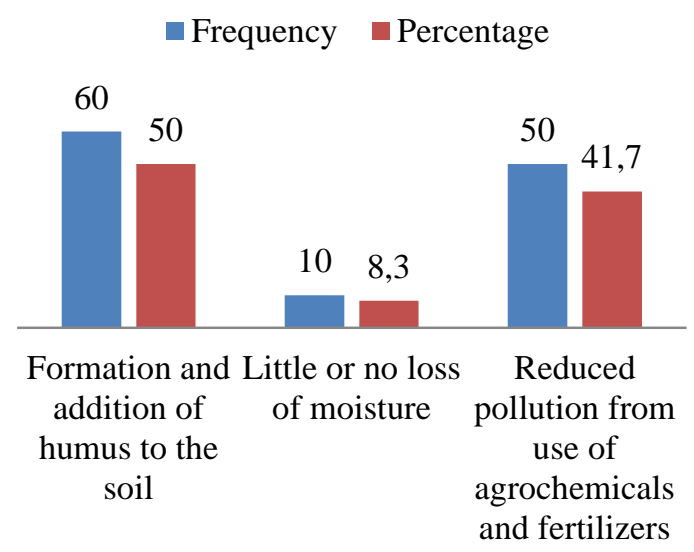

Figure 2

Benefits of using spent plantain pseudostems to grow vegetables to the environment (Source: Field Survey, 2020)

\subsection{Constraints to adopting the innovation}

Results from Table 3 show that Low market prices of vegetables ranked the $1^{\text {st }}$ among constraints encountered by farmers who adopt this innovation. They take time to tend for their plants during the dry season only to take their produce to the markets and it is priced very low. Lack of access to improved/hybrid seed ranked the $2^{\text {nd }}$. In contrast, high cost of seeds and invasion of farms by herds ranked the $3^{\text {rd }}$ respectively and shortness of the shelf life of vegetables ranked the $5^{\text {th }}$ principally because farmers wish the fresh vegetable stays longer and service the consumers in the dry season and absence of extension education and farm advisory services ranked the least ( $6^{\text {th }}$ position) among the challenges encountered by farmers in the adopting of this innovation.

Table 3

Constraints to adopting the innovation

\begin{tabular}{|c|c|c|c|}
\hline Variable & Frequency & Percentage & Rank \\
\hline $\begin{array}{l}\text { Low market prices of } \\
\text { vegetables }\end{array}$ & 30 & 25.0 & $1^{\mathrm{st}}$ \\
\hline High cost of seeds & 20 & 16.7 & $3^{\text {rd }}$ \\
\hline $\begin{array}{l}\text { Lack of access to } \\
\text { improved seed }\end{array}$ & 25 & 20.8 & $2^{\text {nd }}$ \\
\hline No extension education & 10 & 8.3 & $6^{\text {th }}$ \\
\hline $\begin{array}{l}\text { Short shelf life of } \\
\text { vegetables }\end{array}$ & 15 & 12.5 & $5^{\text {th }}$ \\
\hline Herds invasion of farm & 20 & 16.7 & $3^{\text {rd }}$ \\
\hline
\end{tabular}

\section{Conclusion and Recommendation}

We conclude this study by stating that, growing vegetables with spent plantain psuedostem is a female dominated activity. Lettuce and Spinach were the prevalent leafy vegetables grown using the innovation. Leafy vegetable production is profitable and cost effective in the study area. Decaying pseudostems adding to the manure to the soil through humus formation and reduced pollution from agrochemicals and fertilizers were some of the perceived environmental impacts of the innovation. Low market prices of vegetables, shortness of the shelf life of vegetables, costs of seeds were the major challenges encountered by farmers who adopted the innovation. We are of the option that the innovation was viable with possibility of expansion. The study recommends further drive of the innovation to other plantain producing regions of Nigeria, plantain farmers are also encouraged to explore other uses of their farm 'waste', environmental specialist and other promoters of ecofriendly production and investors should partner with these plantain producers to add value to products and 'wastes'. The right and supporting policies to sustain the adoption of the innovation should also be put in place by the authorities concerned.

\section{References}

Adeoye IB, Oni OA, Yusuf SA, Adenegan KO (2013). Plantain Value Chain Mapping in Southwestern Nigeria. Journal of Economics and Sustainable Development 4 (16): 137-145

Ahmar M (2021). Using Plantain stems to grow vegetables - Organic farming innovation. Health and Fitness, Home, Sustainability, Tech - Green Ubuntu. Retrieved March 20, 2021, from http://greenubuntu.com/use-banana-stems-organicfarming-innovations-agriculture/

Ajiboye GA, Olaniyan JO (2016). Characteristics and suitability evaluation of the "white soils" of Etung local government area for oil palm and plantain production. Agrosearch 16 (2): 25-40

Akinyemi SOS, Adejoro MA, Layade AA, Adegbite OO (2017). Market Structure and Performance for Plantain and Banana. International Journal of Fruit Science. 17(4): 440-450.

Belewu MA, Belewu KY (2005): Cultivation of mushroom (Volvariella volvacea) on banana leaves. African Journal of Biotechnology 4(12): 1401-1403

Ekunwe PA, Ajayi HI (2010). Economics of Plantain Production in Edo State Nigeria. Research Journal of Agriculture and Biological Sciences 6(6): 902905

Elum ZA, Tigiri HD (2018). Socioeconomic factors influencing plantain production in Khana Local Government Area of Rivers State, Nigeria. Journal of Agriculture and Food Sciences 16 (2): 107 -116

FAOSTAT (2018). Food and Agriculture Organization 
of the United Nations: statistics database. Retrieved July 25, 2020, from http://www.fao.org/ faostat/ en/\#data/QC

Imam ZM, Akter S (2011). Musa paradisiaca L. and Musa sapientum L.: A Phytochemical and Pharmacological Review. Journal of Applied Pharmaceutical Science 1(5): 14-20

Kamira M, Sivirihauma C, Ntamwira J, Ocimati W, Katungu MG, Bigabwa JB, Vutseme L, Blomme G (2015). Household uses of the banana plant in eastern Democratic Republic of Congo. Journal of Applied Biosciences 94: 8915 - 8929.

Lekshmi PS (2018). Biodegradable and Moisture-Rich, Banana Stems Are Great For Growing Veggies at Home!. Retrieved July 25, 2020, from https://www.thebetterindia.com/146862/newsbanana-stems-growing-veggies-at-home-indonesiaindian-farmers/

Mohapatra D, Mishra S, Sutar N (2010). Banana and its by-product utilisation: an overview. Journal of Scientific and Industrial Research 69: 323-329

Obalola TO, Agboola BO, Odum EBE (2017). Profitability and constraints to irrigated onion production in Wamakko and Kware Local Government Areas, Sokoto State, Nigeria. Journal of Global Agriculture and Ecology 7(3): 106-110

Obi FO, Ugwuishiwu BO, Nwakaire JN (2016). Agricultural Waste Concept, Generation, Utilization and Management. Nigerian Journal of Technology 35(4): 957 - 964

Ojediran EO, Adewumi MO, Falola A, Ibrahim HK, Belewu KY, Oyedeji OA (2018). Analysis of the determinants of plantain supply by small holder farmers in Osun State, Nigeria. Agrosearch 18(1): $15-24$.

Okoli IC (2020a): Banana and Plantain Wastes 1: Production dynamics and important uses. Retrieved
July 25, 2020, from https://researchtropica. com/banana- and-plantain-wastes-1/. Accessed 25th July 2020

Okoli IC (2020b). Banana and Plantain Wastes 2: Fiber and other products from the pseudostem. Tropical Research Reference Platform. Retrieved July 25, 2020, from https://researchtropica.com/banana-andplantain-wastes-2/

Okoli IC (2020c). Banana and Plantain Wastes 3: Use of pseudostem and leaves as animal feed. Retrieved July 25, 2020, from https://researchtropica .com/banana-and-plantain-wastes-3/)

Phirke NV, Patil RP, Chincholkar SB, Kothari RM (2001). Recycling of banana pseudostem waste for economical production of quality banana. Resource Conservation and Recycling 31: 347-353

Sabiti EN (2011). Utilizing Agricultural waste to enhance food security and conserve the Environment. African Journal of Food, Agriculture, Nutrition and Development 11(6): 1 - 9.

Talabi JY, Osukoya OA, Ajayi OO, Adegoke GO (2016). Nutritional and antinutritional compositions of processed Avocado (Persea americana Mill) seeds Asian Journal of Plant Science and Research 6(2): 6-12

Toborn J (2011). Adoption of Agricultural Innovations, Converging Narratives, and The Role of Swedish Agricultural Research for Development. Discussion Paper, Version 2011-01-28

USDA (2012). United States Department of Agriculture. Nutrient data laboratory. Retrieved July 25, 2020, from http://www.nal.usda.gov/fnic/ foodcomp/data/SR $8 / \mathrm{sr}^{\prime} 18 . \mathrm{html}$

Violette R (2019). 10 Uses of Banana Trees, Dengardens, Retrieved July 25, 2020, from https://dengarden.com/gardening/10-Uses-OfBanana-Plants 